\title{
Establishing a Multicolor Flow Cytometry to Characterize Cellular Immune Response in Chickens Following H7N9 Avian Influenza Virus Infection
}

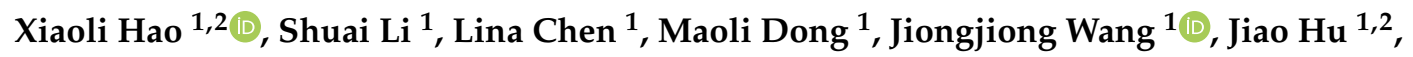 \\ Min Gu ${ }^{1,2}$, Xiaoquan Wang ${ }^{1,2}$, Shunlin $\mathrm{Hu}^{1,2,3}$, Daxin Peng ${ }^{1,2,3}$, Xiufan Liu 1,2,3,4,* \\ and Shaobin Shang $1,2,3,4, *$ \\ 1 College of Veterinary Medicine, Yangzhou University, Yangzhou 225009, China; xlhao@yzu.edu.cn (X.H.); \\ lsmuzi98@163.com (S.L.); CLN18762314118@163.com (L.C.); 18627057287@163.com (M.D.); \\ wjiongjiong@163.com (J.W.); hujiao@yzu.edu.cn (J.H.); gumin@yzu.edu.cn (M.G.); wxq@yzu.edu.cn (X.W.); \\ slhu@yzu.edu.cn (S.H.); pengdx@yzu.edu.cn (D.P.) \\ 2 Institute of Comparative Medicine, Yangzhou University, Yangzhou 225009, China \\ 3 Jiangsu Co-innovation Center for Prevention and Control of Important Animal Infectious Diseases and Zoonosis, \\ Yangzhou University, Yangzhou 225009, China \\ 4 International Corporation Laboratory of Agriculture and Agricultural Products Safety, Yangzhou University, \\ Yangzhou 225009, China \\ * $\quad$ Correspondence: xfliu@yzu.edu.cn (X.L.); shaobinshang@yzu.edu.cn (S.S.); Tel.: +86-514-879-914-16 (X.L.); \\ $+86-514-879-770-81$ (S.S.)
}

Academic Editors: Marios Koutsakos and Sophie Valkenburg

Received: 30 October 2020; Accepted: 3 December 2020; Published: 6 December 2020

\begin{abstract}
Avian influenza virus (AIV) emerged and has continued to re-emerge, continuously posing great threats to animal and human health. The detection of hemagglutination inhibition (HI) or virus neutralization antibodies (NA) is essential for assessing immune protection against AIV. However, the HI/NA-independent immune protection is constantly observed in vaccines' development against H7N9 subtype AIV and other subtypes in chickens and mammals, necessitating the analysis of the cellular immune response. Here, we established a multi-parameter flow cytometry to examine the innate and adaptive cellular immune responses in chickens after intranasal infection with low pathogenicity H7N9 AIV. This assay allowed us to comprehensively define chicken macrophages, dendritic cells, and their MHC-II expression, NK cells, $\gamma \delta \mathrm{T}$ cells, B cells, and distinct T cell subsets in steady state and during infection. We found that NK cells and $\mathrm{KUL} 1^{+}$cells significantly increased after H7N9 infection, especially in the lung, and the KUL01 ${ }^{+}$cells upregulated MHC-II and CD11c expression. Additionally, the percentages and numbers of $\gamma \delta \mathrm{T}$ cells and CD8 T cells significantly increased and exhibited an activated phenotype with significant upregulation of CD25 expression in the lung but not in the spleen and blood. Furthermore, B cells showed increased in the lung but decreased in the blood and spleen in terms of the percentages or/and numbers, suggesting these cells may be recruited from the periphery after H7N9 infection. Our study firstly disclosed that H7N9 infection induced local and systemic cellular immune responses in chickens, the natural host of AIV, and that the flow cytometric assay developed in this study is useful for analyzing the cellular immune responses to AIVs and other avian infectious diseases and defining the correlates of immune protection.
\end{abstract}

Keywords: cellular immune response; flow cytometry; avian influenza virus; H7N9; chicken 


\section{Introduction}

Avian influenza A (H7N9) virus has posed a dual challenge to public health and the poultry industry since its emergence in 2013 in China [1]. Although the isolation of H7N9 AIV field strains have dropped dramatically in both chicken and humans after massive immunization of poultry with $\mathrm{H} 5 / \mathrm{H} 7$ vaccine in chickens since 2017 in China [2], H7N9 variants that are well-adapted in waterfowls have surfaced recently in poultry with higher pathogenicity in chickens and have caused human infection [2,3]. Many vaccine candidates against AIV H7N9 subtype, including inactivated vaccine [4] and HA-carrying recombinant vector vaccine $[5,6]$ have been developed and experimentally shown protection against H7N9 in mice and humans [7]. However, these vaccines induced a low level of hemagglutination inhibition (HI), and viral neutralizing antibodies (NA) titers against the H7N9 subtype that was lower than the standard of vaccine evaluation $\left(>2^{4}\right)$ for other influenza A subtypes (e.g., H1N1 and H5N1) [8] and seasonal influenza viruses. They were also not well correlated with the immune protection conferred by these vaccines $[5,6]$. Similarly, in chickens, our previous studies showed that recombinant Newcastle disease virus (NDV) vaccine carrying H7N9 HA gene (rNDV-H7N9 HA) provided complete protection but did not induce a high level of HI and NA $[9,10]$. This suggests that HI/NA-independent immune protection may play dominant roles, especially for the H7N9 subtype, and that the detection of a humoral response by traditional serological assay may not be sufficient to evaluate the efficacy of vaccines [11] properly. Thus, it is necessary to develop new methods to analyze cellular immune response in poultry after infection or vaccination [12].

In addition to the humoral response, it is well established that cell-mediated immunity plays an important role in protecting against influenza A virus (IAV) in mammals [13-15]. IAV infects airway epithelial cells and triggers the expression of inflammatory cytokines and chemokines, which recruit innate immune cells such as neutrophils, monocytes, and macrophages into the lung to dampen the early stages of IAV infection [16] or promote the immunopathology. In the meantime, respiratory dendritic cells (DCs) become maturated, upregulating the expression of major histocompatibility complex class II (MHC-II) and co-stimulatory molecules, sampling and processing viral antigens to present to CD4 and CD8 T cells $[17,18]$ and initiating the priming of adaptive immune responses. Both CD4 and CD8 T cells can confer homologous and heterologous protection against influenza virus in an antigen-specific manner [13,15]. In addition, NK cells are required for the clearance of influenza virus $[19,20]$, and $\gamma \delta \mathrm{T}$ cells are activated and show a protective function to human and avian (H5N1) influenza virus $[14,21,22]$. While the cellular immunity against influenza A virus in mice and humans has been extensively investigated [13,14], the analysis of cellular immune response in poultry after AIV infection or vaccination has long been neglected.

Chickens are natural hosts for AIV and responsible for the emergence of novel AIV subtypes and their transmission to humans [2]. To better understand the immune response of chicken after AIV infections would facilitate the development of new control strategies in poultry. By depleting chicken CD8 T cells, it has been demonstrated that chicken CD8 T cells can mediate protection against the H5N1 subtype [23]. $\mathrm{CD}^{-} \mathrm{CD} 8 \alpha^{+} \mathrm{NK}$ cells in the lung were found to be activated differentially after AIV H5N1 and H9N2 infection and correlated inversely with pathogenicity in chicken [24]. How chicken immune cells other than CD8 and NK cells respond to AIV infection or immunization has not been examined.

Flow cytometry has emerged as an essential and powerful tool that offers to simultaneously detect multiple parameters at a single cell level and precisely define the phenotypes and functions of distinct immune cell subsets [25]. In recent years, flow cytometry was applied in chicken to differentiate leukocytes from thrombocytes by detecting CD45 expression and side scatter properties [26] to assess the frequency of chicken CD4, CD8, and $\gamma \delta \mathrm{T}$ cells and their expression of activation markers CD44 and CD45 after NDV infection [27,28], and to quantify absolute numbers of white blood cells in blood including thrombocyte, monocyte, T-cell, B-cell, and heterophilic granulocyte, without the need to remove nucleated erythrocytes and thrombocytes [29]. However, flow cytometric assessment of 
the cellular immune response of chicken after AIV infection, in particular H7N9 subtype, has not been investigated.

In this study, we developed a multi-parameter flow cytometry by using a combination of antibodies to chicken markers Bu-1, monocyte/macrophage (KUL01), CD45, MHC-II, CD11c, CD3, CD8 $\alpha$, CD8 $\beta$, $\mathrm{TCR} \gamma \delta, \mathrm{CD} 4$, and $\mathrm{CD} 25$ to comprehensively numerate innate and adaptive immune cell populations in chicken at steady state and after H7N9 infection, leading to an in-depth analysis of the cellular composition and dynamics within lymphoid and non-lymphoid tissues. We found H7N9 infection induced distinct local and systemic cellular immune responses in chickens.

\section{Materials and Methods}

\subsection{Ethics Statement}

All experiments involving live H7N9 viruses were approved by the Institutional Biosafety Committee of Yangzhou University and were performed in animal biosafety level 3 (ABSL-3) facilities in accordance with the institutional biosafety manual (CNAS BL0015). The protocols for all animal studies were approved by Jiangsu Province Administrative Committee for Laboratory Animals (approval number: SYXK-SU-2017-0007) and complied with the guidelines of Jiangsu Province Laboratory Animal Welfare and ethics of Jiangsu Province Administrative Committee of Laboratory Animals.

\subsection{Virus and Animal Experiments}

A low pathogenic AIV (LPAIV) H7N9 (A/Chicken/Anhui/AH395/2017) was used for the infection of chickens [30]. Viruses were propagated in specific pathogen-free (SPF) embryonated chicken eggs. Four-week-old SPF White Leghorn chickens were divided into two groups. One group was mock-infected (uninfected) and the other group was infected intranasally (i.n.) with $10^{5.0}$ EID $_{50}$ of the virus in $0.1 \mathrm{~mL}$ (infected). Six chickens per group were humanely euthanized at 7, 14, and 28 days post-infection (dpi), and tissue samples including spleen, cecal tonsil, lung, thymus, bursa, blood, and bone marrow were harvested for cell isolation.

\subsection{Cell Isolation}

Single-cell suspensions from tissues were prepared as in a previous study [31], and peripheral blood mononuclear cells (PBMC) were isolated from blood as per previous reports [32]. Briefly, the organs were mechanically disrupted and pushed through a 70- $\mu \mathrm{m}$ cell strainer (Corning Inc., Corning, NY, USA) using the plungers of $5 \mathrm{~mL}$ syringe. The cells were resuspended in $10 \mathrm{~mL}$ with phosphate-buffered saline (PBS) containing 2\% fetal bovine serum (FBS). Lung was cut into small pieces and digested with collagenase IV ( $1 \mathrm{mg} / \mathrm{mL}$; Sigma, St. Louis, MO, USA) and DNase I ( $30 \mu \mathrm{g} / \mathrm{mL}$; Sigma, St. Louis, MO, USA) for $30 \mathrm{~min}$ at $37^{\circ} \mathrm{C}$ before disruption. Cell suspensions were overlaid onto the tissue separation medium at a 1:1 ratio to isolate mononuclear cells according to the manufacturer's instructions (Haoyang, Tianjin, China). After centrifugation at room temperature for $30 \mathrm{~min}$ at $500 \times g$, the interface was collected and washed twice with PBS. After centrifugation at $400 \times g$ for $10 \mathrm{~min}$, cells were resuspended in $5 \mathrm{~mL}$ of complete medium (CM; RPMI-1640 supplement with 10\% FBS (Gibco, Grand Island, NY, USA), $1 \%$ penicillin plus streptomycin (Invitrogen, Carlsbad, CA, USA)). To isolate PBMCs, whole blood containing anti-coagulant heparin sodium was diluted with an equal volume of PBS and layered on Histopaque-1077 (Sigma-Aldrich, Poole, UK) and subjected to the above procedures. Red blood cells were lysed with RBC lysis buffer (Gibco, Grand Island, NY, USA) for $5 \mathrm{~min}$. Bone marrow cells were isolated, as described previously [33]. Briefly, bone marrow cells were flushed out from bones with PBS and pushed through a $70 \mu \mathrm{m}$ nylon cell strainer, and the resultant cell suspensions were loaded onto an equal volume of Histopaque-1119 (Sigma-Aldrich, Poole, UK) and centrifuged at $1200 \times g$ for $30 \mathrm{~min}$. Cells at the interface were collected, washed twice with PBS, 
and resuspended in CM. Cells were counted using a hemocytometer (Sigma-Aldrich, St. Louis, MO, USA) and trypan blue, and the final cell concentration was adjusted to $2 \times 10^{7}$ live cells $/ \mathrm{mL}$.

\subsection{Flow Cytometry}

Cells were plated on 96-well V-bottom plate with $2 \times 10^{6}$ cells each well in $100 \mu \mathrm{L}$ FACS buffer $(0.5 \%$ FBS in PBS). Monoclonal antibodies (mAb) specific for chicken B cells (Bu-1), monocyte/macrophage (KUL01), CD45, MHC-II, CD3, CD8 $\alpha, \mathrm{CD} 8 \beta, \mathrm{TCR} \gamma \delta, \mathrm{CD} 4$, and CD25 with different fluorochrome conjugate were purchased from Southern Biotech (Birmingham, AL, USA) and polyclonal antibody $(\mathrm{pAb})$ to human CD11c were purchased from Beijing Biosynthesis Biotechnology Co., Ltd. (Bioss, Beijing, China) (Table 1). Two panels of antibody cocktails were made to distinguish different immune cells: Panel 1 was used to identify chicken B-cells and myeloid lineage (monocytes, macrophages, and dendritic cells) containing anti-monocyte/macrophage-PE, anti-CD45-PerCP-Cy5.5, anti-Bu-1-FITC, anti-MHC-II-PE/cy7, and anti-CD11c-APC. Panel 2 was used to define chicken T cell subsets, NK cells and their activation state containing anti-TCR $\gamma \delta$-BV510, anti-CD3-PerCP-Cy5.5, anti-CD4-Pacific blue, anti-CD8 $\beta$-PE, anti-CD8 $\alpha$-Alexa eFluor 700, and anti-CD25-FITC. Isotype antibodies or fluorescence minus one (FMO) for CD11c, MHC-II, and CD25 were used to set gating. The cells were incubated with $1 \%$ chicken serum to block FC receptors and then stained with fixable viability dye (FVD) eFluor 780 (Thermo Fisher Scientific, Waltham, MA, USA) for excluding dead cells. After centrifugation, a final volume of $50 \mu \mathrm{L}$ antibody cocktail was added to the cells and incubated for $30 \mathrm{~min}$ at $4{ }^{\circ} \mathrm{C}$. After washing twice and centrifugation at $400 \times g$ for $5 \mathrm{~min}$ at $4{ }^{\circ} \mathrm{C}$, the cells were resuspended in $200 \mu \mathrm{L}$ PBS for FACS analysis. Flow cytometry was performed with a FACS LSRFortessa (BD Biosciences, Franklin Lakes, NJ, USA) and a minimal number of 100,000 cells was acquired. Data analysis was processed by FlowJo software (Tree Star Inc., Ashland, OR, USA), and the total cell number of indicated subset per organ or $5 \mathrm{~mL}$ blood was subsequently calculated.

Table 1. Antibodies used for flow cytometry in this study.

\begin{tabular}{ccccc}
\hline Marker & Clone & Isotype & Conjugate & Purpose \\
\hline Panel 1 & & & \\
\hline CD45 & LT40 & mouse IgM & PerCP-Cy5.5 & Leukocytes \\
Bu-1 & AV20 & mouse IgG1 & FITC & B cells \\
Monocyte/macrophage & KUL01 & mouse IgG1 & PE & Monocytes and macrophages \\
MHC Class II & 2 G11 & mouse IgG1 & PE-Cy7 & DC lineage marker \\
CD11c & polyclonal & rabbit IgG & APC & DC lineage marker \\
Dead Cell Stain & - & - & FVD eFluor 780 & Live cell \\
\hline Panel 2 & & & & \\
CD3 & CT-3 & mouse IgG1 & PerCP-Cy5.5 & T cells \\
TCR $\gamma \delta$ & TCR-1 & mouse IgG1 & Biotin & T cells \\
CD8 $\alpha$ & CT-8 & mouse IgG1 & AF700 & CD $8^{+}$T cells \\
CD8 $\beta$ & EP42 & mouse IgG2a & PE & CD8 ${ }^{+}$T cells \\
CD4 & CT-4 & mouse IgG1 & Pacific blue & CD4 ${ }^{+}$T cells \\
CD25 & AV142 & mouse IgG1 & FITC & Activation \\
Streptavidin & - & - & BV510 & - \\
Dead Cell Stain & - & - & FVD eFluor 780 & Live cell \\
\hline
\end{tabular}

\subsection{Statistical Analysis}

Statistically significance between experimental groups was determined using the independentsamples t-test in the SPSS statistics software (SPSS 23.0, IBM, Ehningen, Germany). $p$ values $<0.05$ were defined as statistically significant. 


\section{Results}

\subsection{Establishing a Polychromatic Flow Cytometry to Define Different Immune Cells in Chicken}

Based on the availability of antibodies against surface markers of chicken immune cells commercially and optimal combination of different fluorochrome conjugates (Table 1), a multi-parameter flow cytometry was established, allowing us to simultaneously define different T cell subsets, NK cells, and their activation state or antigen-presenting cells (APCs) including B cells, monocytes/macrophages in one panel. All the antibodies used were titrated to an optimal concentration. A gating strategy for immunophenotyping antigen-presenting cells and T cell subsets are shown in Figures 1 and 2, respectively. For Panel 1, CD45-positive leukocytes were gated (Figure 1A) and singlet cells were chosen (Figure 1B), then dead cells were excluded (Figure 1C). Next, by outputting forward scatter (FSC) versus side scatter (SSC), lymphocytes were located in a dot-plot (Figure $1 \mathrm{~F}$ ) and Bu-1 ${ }^{+} \mathrm{B}$ cells were defined (Figure 1I). By excluding B cells (Figure 1E) and outputting KUL01 vs MHC-II, we could define KUL01 ${ }^{+}$ cells (Figure 1D), which were MHC-II-positive, and consisted of two subsets, KUL01 ${ }^{\text {lo } M H C-I I ~}{ }^{\text {hi }}$ and KUL01 $^{\text {hi MHC-II }}{ }^{\text {lo }}$ (Figure 1G), and further analysis showed that KUL01 ${ }^{\text {lo }}$ MHC-II ${ }^{\text {hi }}$ subsets, but not KUL01 ${ }^{\text {hi MHC-II }}{ }^{\text {lo }}$, partially expressed CD11c (Figure 1H).

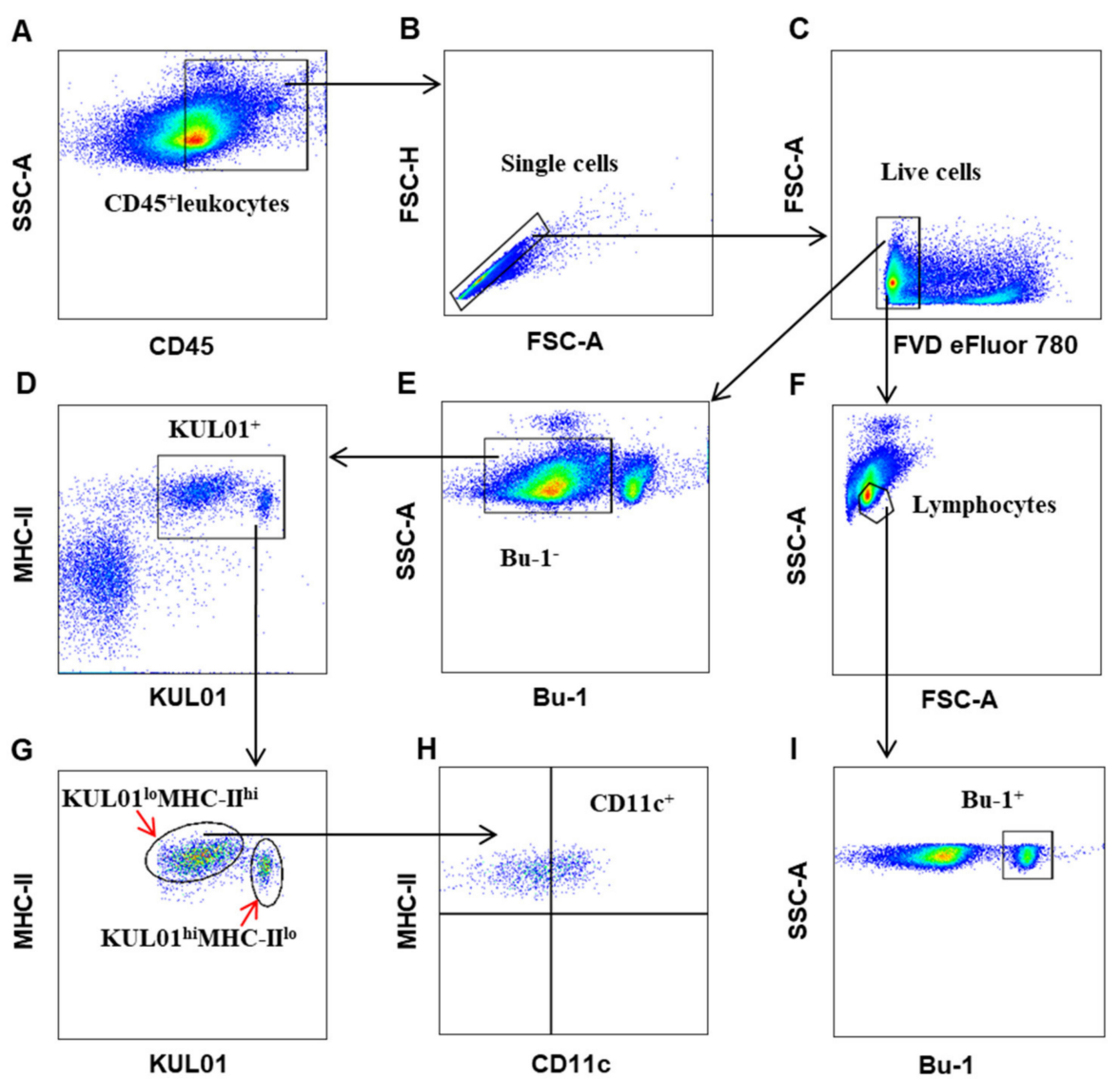

Figure 1. Gating strategies to identify chicken B-cells and myeloid lineage. Mononuclear cells were isolated from spleens of 4 weeks-old naïve chicken and surface stained with antibody cocktails (panel 1: CD45, Bu-1, KUL01, MHC-II, CD11c, and FVD eFluor 780). The leukocytes were gated with CD45 positive (A) and then single cells were gated based on size and granularity using FSC-A and FSC-H (B). Live cells were defined as FVD eFluor 780-negative (C). Then, the lymphocytes were chosen (F) using forward scatter (FSC)-A and SSC-A, and Bu-1 $1^{+} \mathrm{B}$ cells were defined (I). By excluding Bu- $1^{+} \mathrm{B}$ cell (E) and outputting KUL01 vs MHC-II, the KUL01 ${ }^{+}$cells were identified (D), which were further subdivided into KUL01 ${ }^{\text {lo }}$ MHC-II ${ }^{\text {hi }}$ and KUL01 ${ }^{\text {hi }}$ MHC-II ${ }^{\text {lo }}$ cells (G). Finally, partial CD11c expression was confirmed on the KUL01 ${ }^{\text {lo }}$ MHC-II ${ }^{\text {hi }}$ cells but not on the KUL01 ${ }^{\text {hi }}$ MHC-II ${ }^{\text {lo }}$ cells $(\mathbf{H})$. 
A

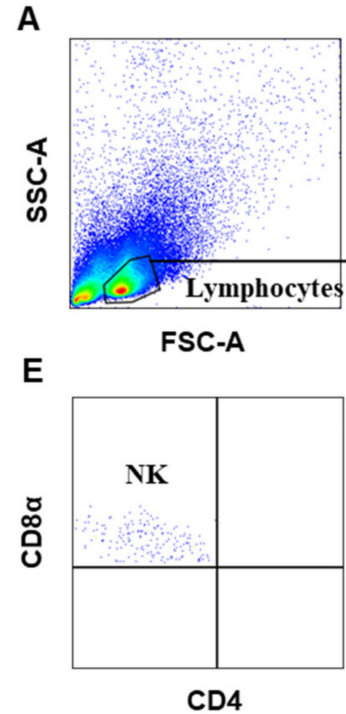

I

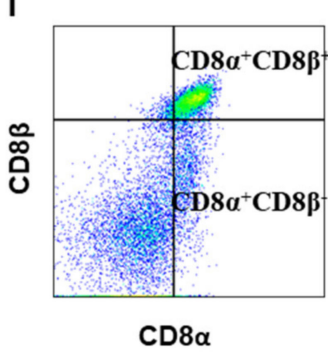

B

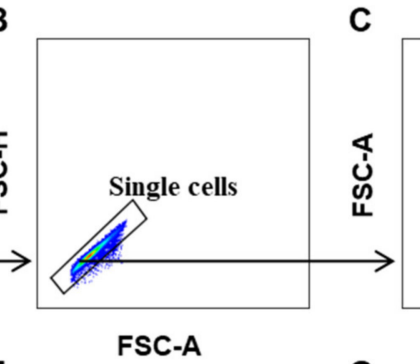

$\mathbf{F}$

G
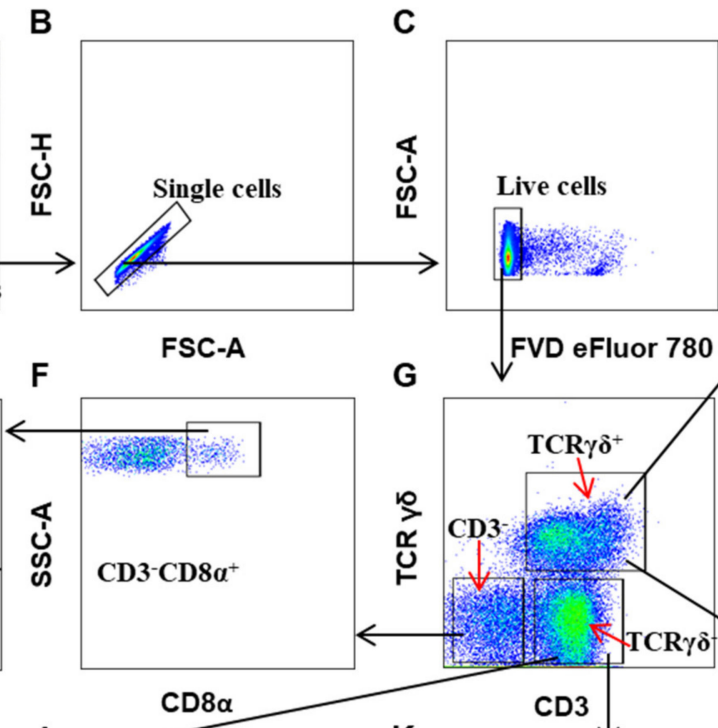
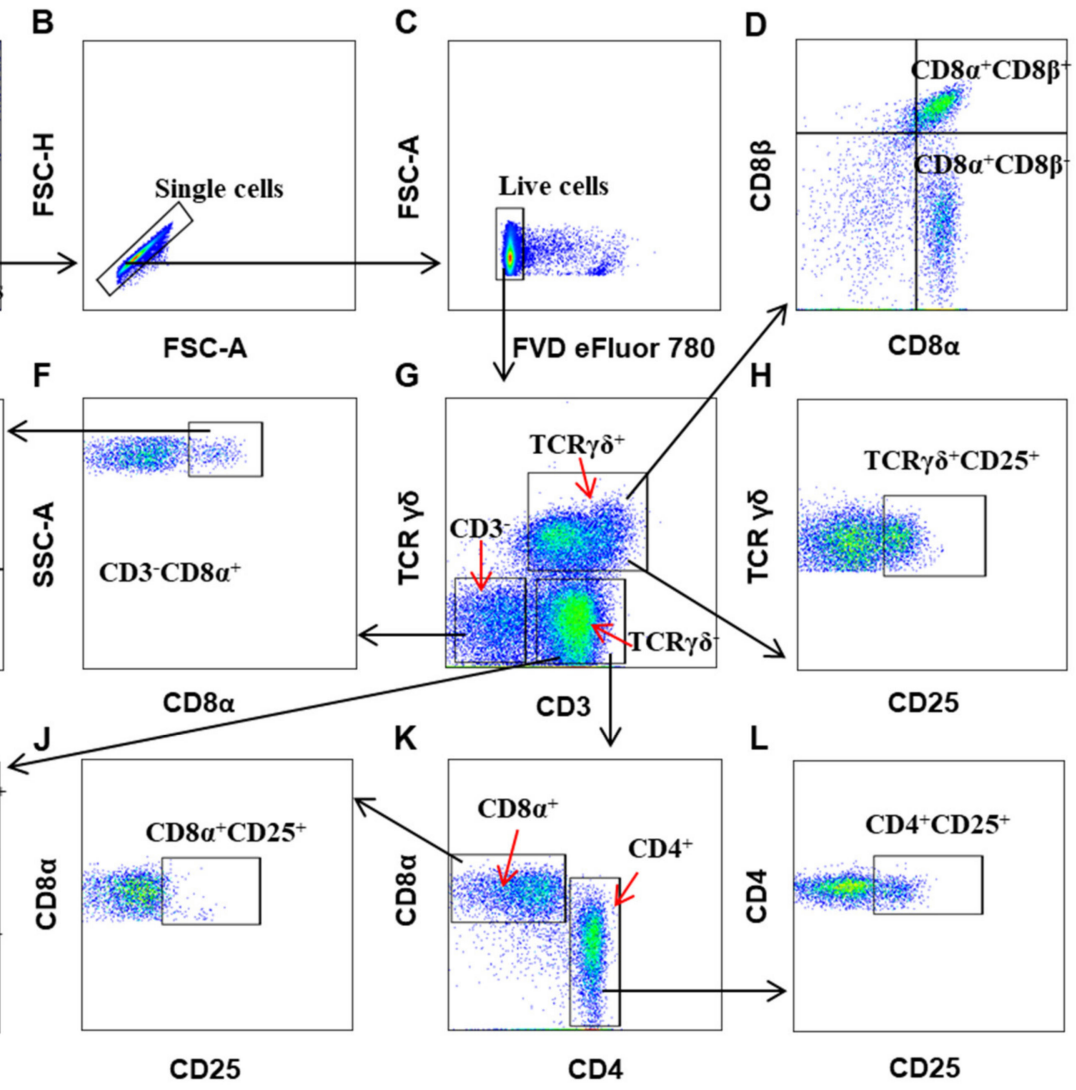

$\mathbf{L}$

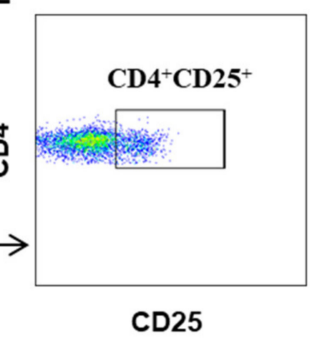

Figure 2. Gating strategies to define chicken $\mathrm{T}$ cell subsets, NK cells, and their activation state. Mononuclear cells were isolated from spleens of 4 weeks-old naïve chicken and surface stained with antibody cocktails (Panel 2: CD3, TCR $\gamma \delta, \mathrm{CD} 4, \mathrm{CD} 8 \alpha, \mathrm{CD} 8 \beta, \mathrm{CD} 25$, and FVD eFluor 780). The lymphocytes are chosen with FSC versus SSC (A), and then single cells were gated using FSC-A and FSC-H (B). Live cells were defined as FVD eFluor 780-negative (C). By outputting CD3 versus TCR $\gamma \delta$, $\mathrm{CD}^{+} \mathrm{TCR} \gamma \delta^{+}\left(\gamma \delta \mathrm{T}\right.$ cells), $\mathrm{CD} 3^{+} \mathrm{TCR} \gamma \delta^{-}$, and $\mathrm{CD} 3^{-} \mathrm{TCR} \gamma \delta^{-}$cells were identified, respectively (G). The $\mathrm{CD}^{-} \mathrm{TCR} \gamma \delta^{-}$non-T cell population contained CD3-CD8 $\alpha^{+} \mathrm{NK}$ cells $((\mathbf{E}, \mathbf{F}))$. CD3 ${ }^{+} \mathrm{TCR} \gamma \delta^{-} \mathrm{T}$ cells contained $\mathrm{CD}^{+}\left(\mathrm{TCR} \gamma \delta^{-} \mathrm{CD} 3^{+} \mathrm{CD} 4^{+}\right)$and $\mathrm{CD} 8 \alpha^{+} \mathrm{T}$ cells $\left(\mathrm{TCR} \gamma \delta^{-} \mathrm{CD} 3^{+} \mathrm{CD} 8 \alpha^{+}\right)(\mathrm{K})$. Both $\gamma \delta \mathrm{T}$ cells and $\mathrm{CD} 8 \alpha^{+}$T cells $\left(\mathrm{TCR} \gamma \delta^{-} \mathrm{CD} 3^{+}\right)$could be further subdivided into $\mathrm{CD} 8 \alpha \alpha$ and $\mathrm{CD} 8 \alpha \beta$ subsets $((\mathbf{D}, \mathbf{I})$ ). The CD25 expression on $\gamma \delta$ T cells $(\mathbf{H}), \mathrm{CD}^{+}(\mathbf{L})$, and CD8 $\alpha^{+}$T cells $(\mathrm{J})$ were analyzed, respectively.

For panel 2, as shown in Figure 2, lymphocytes were located by FSC/SSC in a dot-plot (Figure $2 \mathrm{~A}$ ), and then the output $\mathrm{CD} 3$ vs $\mathrm{TCR} \gamma \delta, \mathrm{CD} 3^{+} \mathrm{TCR} \gamma \delta^{+} \mathrm{T}$ cells $(\gamma \delta \mathrm{T}), \mathrm{TCR} \gamma \delta^{-} \mathrm{CD} 3^{+} \mathrm{T}$ cells, and $\mathrm{CD}^{-} \mathrm{TCR} \gamma \delta^{-}$non-T cells were defined, respectively (Figure $2 \mathrm{D}$ ). The $\mathrm{CD} 3^{-} \mathrm{TCR} \gamma \delta^{-}$non-T cells population contained $\mathrm{CD}^{-} \mathrm{CD} 8 \alpha^{+}$natural killer (NK) cells that do not express $\mathrm{CD} 4$ (Figure 2F,E) as previously reported [34]. $\gamma \delta$ T cells $\left(\mathrm{CD} 3^{+} \mathrm{TCR} \gamma \delta^{+}\right)$included $\mathrm{CD} 8 \alpha \beta^{+}$and $\mathrm{CD} 8 \alpha \alpha^{+}$subsets (Figure 2D) and expressed CD25 (Figure $2 \mathrm{H}$ ). $\mathrm{CD} 3^{+} \mathrm{TCR} \gamma \delta^{-} \mathrm{T}$ cells comprised $\mathrm{CD} 4^{+}$and $\mathrm{CD} 8 \alpha^{+} \mathrm{T}$ cells (Figure $2 \mathrm{~K}$ ). $\mathrm{CD} 8 \alpha^{+} \mathrm{T}$ cells $\left(\mathrm{CD}^{+} \mathrm{TCR} \gamma \delta^{-}\right)$could also be subdivided into $\mathrm{CD} 8 \alpha \beta^{+}$and $\mathrm{CD} 8 \alpha \alpha^{+}$subsets (Figure $\left.2 \mathrm{I}\right)$ and barely expressed CD25 (Figure 2J), whereas TCR $\gamma \delta^{-} \mathrm{CD}^{+} \mathrm{T}$ cells expressed CD25 apparently (Figure 2L).

\subsection{The Distribution of Immune Cells in Organs of Chicken at Steady State}

As the relative expression of each marker in a given organ/tissue of chicken has not been detected simultaneously, we first measured the leukocyte composition within lymphoid and non-lymphoid tissues in naïve birds (steady state) using the established multicolor flow cytometry. The overall

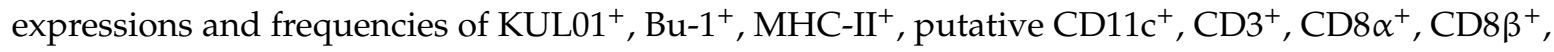
$\mathrm{TCR} \gamma \delta^{+}, \mathrm{CD}^{+}$, and $\mathrm{CD} 25^{+}$cells in different organs/tissues are shown in Figure 3. Intriguingly, 
the frequencies of cells expressing specific markers varied dramatically in different organs. The KUL01 ${ }^{+}$,

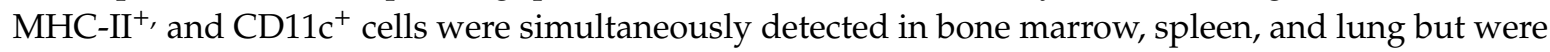
most enriched in bone marrow $(30.8 \%, 38.2 \%$, and $24.8 \%$, respectively) (Figure $3 \mathrm{~A}$ ) and less dominant in the spleen $(8.2 \%, 30.9 \%$, and $17.2 \%$, respectively), and lung (5.4\%, $16.4 \%$, and 6.7\%, respectively). Although $\mathrm{KULO1}^{+}$and $\mathrm{MHC}-\mathrm{II}^{+}$cells were detected in the blood, there were very few CD11c ${ }^{+}$cells. $\mathrm{Bu}-1^{+} \mathrm{B}$ cells are enriched in the bursa (98.7\%) and cecal tonsils (65.3\%) and account for around 31.5\% MHC-II ${ }^{+}$cells in the bursa and showed a hierarchy of percentage in the spleen (28.7\%), lung (15.4\%), blood $(9.5 \%)$, bone marrow $(4.5 \%)$, and thymus $(1.1 \%)$ (Figure 3A,C). There were very few CD11c ${ }^{+}$ cells in the bursa $(2.4 \%)$ but a relatively higher percentage of putative CD11c ${ }^{+}$cells in cecal tonsils $(8.7 \%)$. As anticipated, there were very few B cells and myeloid cells (KUL01 ${ }^{+}, \mathrm{MHC}^{-\mathrm{II}^{+}}$, and CD11c ${ }^{+}$) in the thymus-the organ of $\mathrm{T}$ cell development (Figure 3A,C).

In contrast, $\mathrm{CD}^{+}$total $\mathrm{T}$ cells were most dominant in the thymus (63.3\%), spleen (59.8\%), and blood $(69.4 \%)$, with a lower percentage in bone marrow $(19.3 \%)$, cecal tonsil $(19.8 \%)$, and lung (34.3\%), respectively (Figure 3B,D). However, the proportion of T cell subsets $\left(\mathrm{CD} 8 \alpha^{+}, \mathrm{CD} 8 \beta^{+}\right.$, and CD4 ${ }^{+}$) varied in different organs. While the ratio of CD8 to CD4 were between the normal range of $0.8-1.5$ in spleen $(29 \% / 24.4 \%)$, cecal tonsil $(15.9 \% / 10.2 \%)$, and lung $(12.2 \% / 15.6 \%)$, there was a very low CD8/CD4 ratio $(15.1 \% / 50.3 \%)$ in the blood because of the high percentage of CD4 T cells and considerably high CD8/CD4 ratio $(81.5 \% / 12 \%)$ in the thymus because of the unusually low percentage of CD4 T cells (Figure 3B). The percentage of CD8 $\alpha^{+} \mathrm{T}$ cells was higher than that of $\mathrm{CD} 8 \beta^{+} \mathrm{T}$ cells in most of organs tested, suggesting a proportion of CD8 T cells may use the CD8 $\alpha \alpha$ co-receptor $\left(\mathrm{CD} 8 \beta^{-}\right)$(Figure $3 \mathrm{~B}$ ). The frequency of $\gamma \delta \mathrm{T}$ cells ranged from $2.9 \%$ to $10.4 \%$ with a hierarchy of thymus $>$ spleen $>$ lung $>$ blood $>$ cecal tonsil > bone marrow. As in the organ of B cell development in birds, bursa had barely any T cells. There was a baseline expression of CD25 in these organs except in the thymus and bursa (Figure 3B).

Based on the gating strategy in Figure 2, we further examined the distributions of CD3 ${ }^{-} \mathrm{CD} 8 \alpha^{+}$ NK cells, CD8 $\alpha \alpha^{+}$, and CD8 $\alpha \beta^{+} \gamma \delta$ T cells, CD8 $\alpha \alpha^{+}$and CD8 $\alpha \beta^{+}$T cells, and CD4 ${ }^{+} \mathrm{CD} 25^{+}$regulatory $\mathrm{T}$ cells in different organs (Table 2 ). There were very few NK cells (less than $1 \%$ ) in tested organs, with a relatively high abundance in cecal tonsil $(1 \%)$ and lung $(0.8 \%)$, and no NK cells detectable in the thymus. The distribution of $\mathrm{CD} 8 \alpha \alpha^{+}$and $\mathrm{CD} 8 \alpha \beta^{+} \gamma \delta \mathrm{T}$ cells resembled that of total $\gamma \delta \mathrm{T}$ cells, with the highest percentage in the spleen and lung. While CD $8 \alpha \beta^{+}$T cells were distributed in a hierarchy of thymus $>$ spleen $>$ blood $>$ cecal tonsil $>$ bone marrow $>$ lung, CD8 $\alpha \alpha^{+}$T cells showed a hierarchy of thymus $>$ spleen $>$ cecal tonsil $>$ lung $>$ blood $>$ bone marrow $($ Table 2$) . \mathrm{CD}^{+} \mathrm{CD} 25^{+} \mathrm{T}$ cells were most abundant in bone marrow, cecal tonsil, spleen, and lung and less dominant in the thymus and blood (Table 2). Collectively, these data reveal that distinct immune cells are distributed in different organs of chicken with different abundance at steady state.

Table 2. Distribution of NK and T cell subsets in different organs.

\begin{tabular}{|c|c|c|c|c|c|c|c|}
\hline \multirow{2}{*}{ Leucocyte Type } & \multicolumn{7}{|c|}{ Percentage (\%) } \\
\hline & Bone Marrow & Thymus & Bursa & Spleen & Cecal Tonsil & Lung & Blood \\
\hline $\mathrm{CD}^{-} \mathrm{CD} 8 \alpha^{+} \mathrm{NK}$ cells $^{\mathrm{a}}$ & $0.5 \pm 0.2^{c}$ & $\mathrm{ND}^{\mathrm{d}}$ & $<0.1$ & $0.3 \pm 0.2$ & $1.0 \pm 1.1$ & $0.8 \pm 0.4$ & $0.2 \pm 0.1$ \\
\hline $\mathrm{TCR} \gamma \delta^{+} \mathrm{T}$ cells ${ }^{\mathrm{a}}$ & $5.4 \pm 2.0$ & $6.9 \pm 2.3$ & $0.12 \pm 0.03$ & $12.2 \pm 3.9$ & $4.8 \pm 1.9$ & $13.6 \pm 3.2$ & $6.3 \pm 2.3$ \\
\hline $\mathrm{TCR} \gamma \delta^{+} \mathrm{CD} 8 \alpha \beta^{+} \mathrm{T}_{\text {cells }}{ }^{\mathrm{a}}$ & $0.8 \pm 0.1$ & $0.7 \pm 0.3$ & $<0.1$ & $3.3 \pm 2.2$ & $0.4 \pm 0.3$ & $2.4 \pm 1.3$ & $0.5 \pm 0.4$ \\
\hline $\mathrm{TCR} \gamma \delta^{+} \mathrm{CD} 8 \alpha \alpha^{+} \mathrm{T}$ cells $^{\mathrm{a}}$ & $1.1 \pm 0.3$ & $<0.1$ & $<0.1$ & $3.8 \pm 1.6$ & $1.1 \pm 0.8$ & $2.9 \pm 1.1$ & $0.6 \pm 0.3$ \\
\hline $\mathrm{TCR} \gamma \delta^{-} \mathrm{CD}^{+}{ }^{+} \mathrm{CD} 8 \alpha \beta^{+} \mathrm{T}$ cells ${ }^{\mathrm{a}}$ & $7.4 \pm 1.6$ & $43.6 \pm 7.7$ & $<0.1$ & $23.4 \pm 8.6$ & $8.4 \pm 3.8$ & $5.5 \pm 1.9$ & $11.7 \pm 4.7$ \\
\hline $\mathrm{TCR} \gamma \delta^{-} \mathrm{CD}^{+} \mathrm{CD} 8 \alpha \alpha^{+} \mathrm{T}$ cells ${ }^{\mathrm{a}}$ & $0.9 \pm 0.5$ & $13.1 \pm 9.9$ & $<0.1$ & $5.7 \pm 2.7$ & $2.4 \pm 0.9$ & $2.2 \pm 0.9$ & $0.8 \pm 0.3$ \\
\hline $\mathrm{TCR} \gamma \delta^{-} \mathrm{CD} 3^{+} \mathrm{CD} 4^{+} \mathrm{T}$ cells ${ }^{\mathrm{a}}$ & $2.7 \pm 1.1$ & $5.9 \pm 2.8$ & $<0.1$ & $26.3 \pm 7.8$ & $10.4 \pm 8.2$ & $20.5 \pm 7.2$ & $43.8 \pm 6.8$ \\
\hline $\mathrm{TCR} \gamma \delta^{-} \mathrm{CD} 4^{+} \mathrm{CD} 25^{+} \mathrm{T}$ cells ${ }^{\mathrm{b}}$ & $9.8 \pm 4.6$ & $4.9 \pm 2.7$ & $\mathrm{ND}^{\mathrm{d}}$ & $6.5 \pm 3.5$ & $8.5 \pm 5.9$ & $9.4 \pm 2.9$ & $1.8 \pm 1.3$ \\
\hline
\end{tabular}

a Percentage of T lymphocytes were derived from a lymphocyte gate based on forward scatter (FSC) versus side scatter (SSC). ${ }^{\mathrm{b}}$ Percentages of $\mathrm{CD} 4{ }^{+} \mathrm{CD} 25^{+} \mathrm{T}$ cells are expressed as a percentage out of $\mathrm{CD} 4^{+} \mathrm{T}$ cells. ${ }^{\mathrm{c}}$ Values are means \pm SD. $n=6 .{ }^{\mathrm{d}} \mathrm{ND}$, not detected. 
A

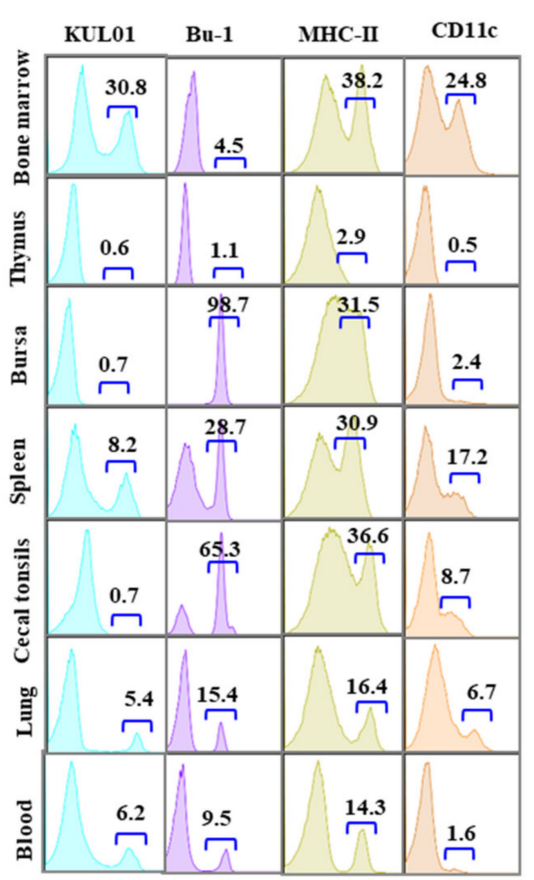

C
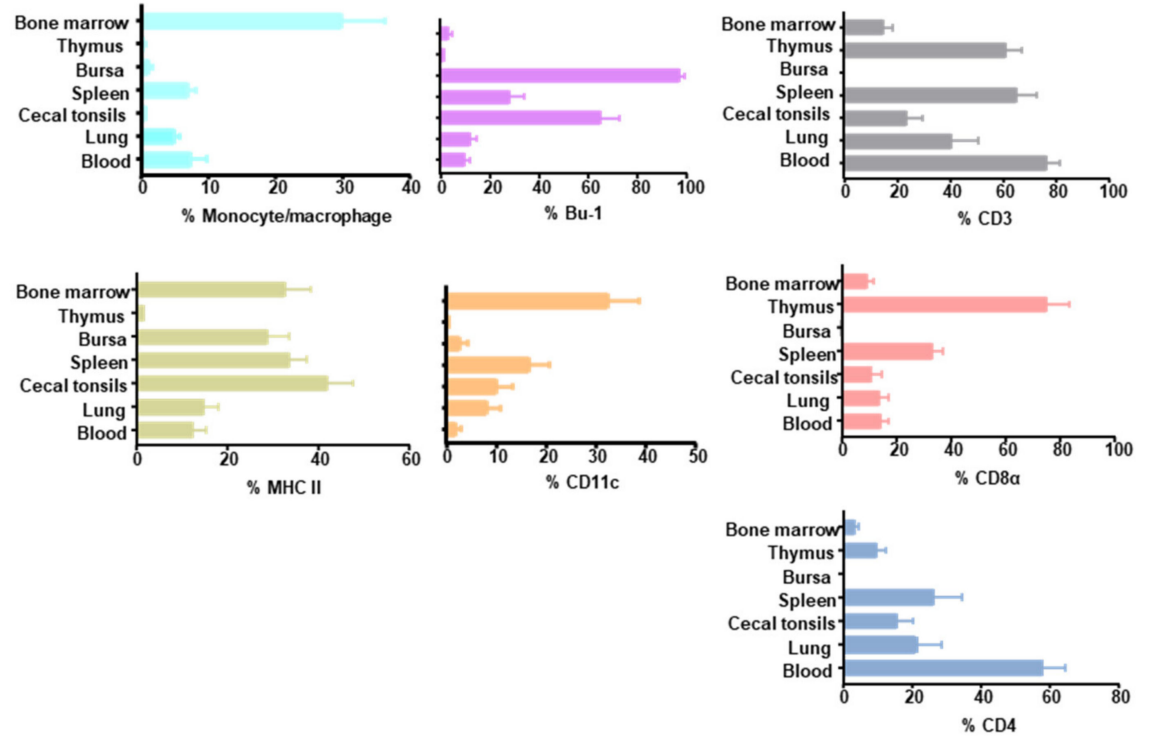

B

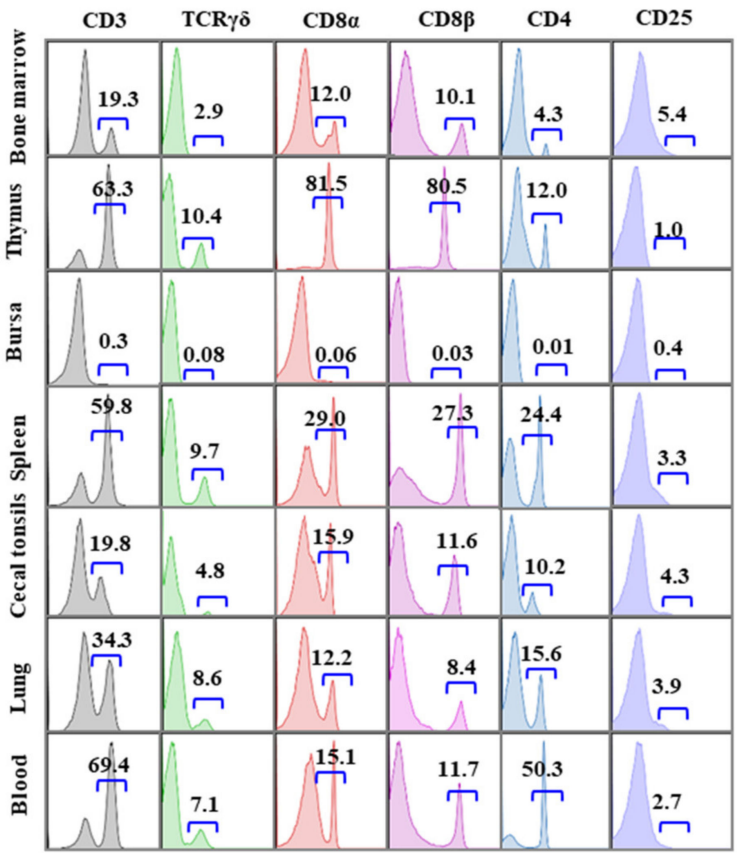

D
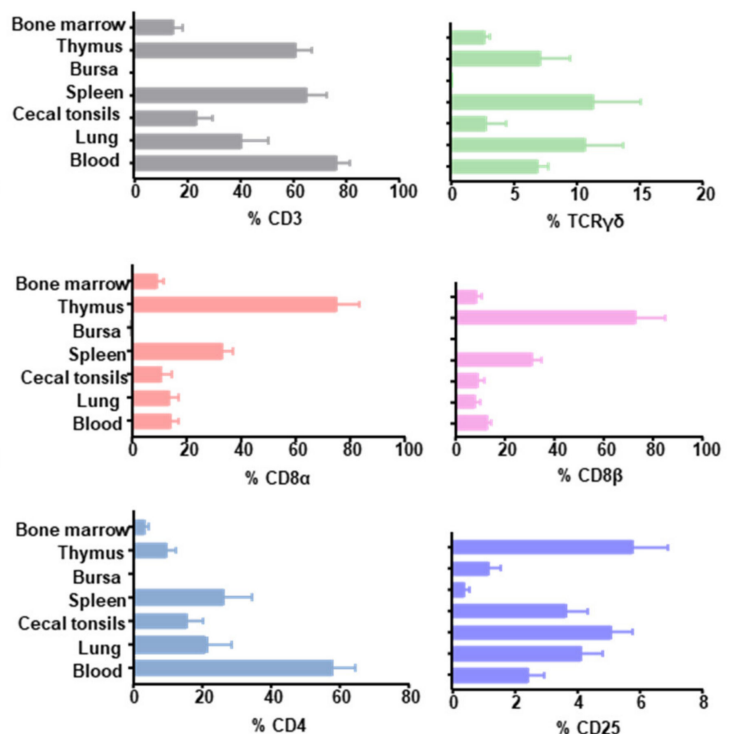

Figure 3. The distribution of immune cells in the organs of chicken at steady state. Mononuclear cells were isolated from different organs of 4 weeks-old naïve chickens and were surface stained with antibody Panel 1 or Panel 2. Representative staining profiles of $\mathrm{KUL}^{+}{ }^{+}, \mathrm{Bu}-1^{+}, \mathrm{MHC}-\mathrm{II}^{+}$, and $\mathrm{CD} 11 \mathrm{c}^{+}$cells by tissue, are depicted as histogram plots (A). Representative staining profiles of $\mathrm{CD}^{+}, \mathrm{TCR} \gamma \delta^{+}, \mathrm{CD} 8 \alpha^{+}$, $\mathrm{CD} 8 \beta^{+}, \mathrm{CD} 4^{+}$, and $\mathrm{CD} 25^{+}$cells by tissue, depicted as histogram plots $(\mathbf{B})$. Results for bone marrow, thymus, bursa, spleen, cecal tonsils, lung, and blood are shown. The percentages of B lymphocytes and $\mathrm{T}$ cell subsets are derived from a lymphocyte gate based on FSC versus SSC. Percentages of KUL01 ${ }^{+}$, MHC-II ${ }^{+}$, putative CD11c ${ }^{+}$cells from a leukocyte gate based on CD45. Bar chart (mean \pm SD) represents total frequency of positive events for each surface marker $((\mathbf{C}, \mathbf{D}))(n=6)$.

\subsection{The Dynamic Changes of Chicken Innate Immune Cells after H7N9 Infection}

Since HI/VN-antibody-independent immune protection was frequently observed in the development of a vaccine against the H7N9 subtype [9,10], we are particularly interested in the changes of the cellular immune response induced by the AIV H7N9 subtype. Firstly, we examined the 
changes in innate immune cells in the spleen, lung, and blood at 7, 14, and 28 dpi using the established flow cytometry. As shown in Figure $4 \mathrm{~A}$, the percentages and absolute numbers of $\mathrm{CD}^{-} \mathrm{CD} 8 \alpha^{+} \mathrm{NK}$ cells significantly increased in the lung at 7 and $14 \mathrm{dpi}$ and in the spleen and blood at $7 \mathrm{dpi}$, compared to the control. Similarly, the percentages and numbers of $\mathrm{KUL} 1^{+}$monocytes/macrophages markedly increased in the lung at 7, 14, and $28 \mathrm{dpi}$ and in the spleen at 7 and $14 \mathrm{dpi}$, and in the blood at $7 \mathrm{dpi}$, compared to the control (Figure 4B). Among KUL01+ cells, there was a subset of KUL01 ${ }^{+}$cells upregulated MHC-II and CD11c expression in the spleen and lung from H7N9-infected chicken in terms of the percentage and mean fluorescence intensity (MFI) (Figure 4C,D), resembling the maturation of monocyte-derived dendritic cells observed in murine infection model [35]. These results suggested that KUL01 ${ }^{+} \mathrm{MHC}-\mathrm{II}^{+} \mathrm{CD} 11 \mathrm{c}^{+}$cells are potentially a subset of antigen-presenting cells in chicken after H7N9 infection. Overall, these data indicated that KUL01+ monocytes/macrophages, putative DC, and $\mathrm{CD}^{-} \mathrm{CD} 8 \alpha^{+} \mathrm{NK}$ participate in host defense against H7N9 infection.

\subsection{The Dynamic Changes of Chicken Adaptive Immune Cells after H7N9 Infection}

Further analysis of the changes of adaptive immune cells after H7N9 infection showed that $\gamma \delta \mathrm{T}$ cells were significantly increased $(p<0.05)$ in the lung at 14 and $28 \mathrm{dpi}$ but not in the spleen and blood at any time-point after H7N9 infection (Figure 5A). Similarly, CD8 $\alpha^{+}$T cells were markedly increased $(p<0.05)$ in the lung at 14 and $28 \mathrm{dpi}$ but started to decrease at $28 \mathrm{dpi}$ in the spleen and blood in terms of the percentage and number (Figure 5B). These results suggested that H7N9 induced a local immune response for $\gamma \delta \mathrm{T}$ and $\mathrm{CD} 8 \alpha^{+} \mathrm{T}$ cells. Differently, CD4 ${ }^{+} \mathrm{T}$ cells significantly increased in the blood at $14 \mathrm{dpi}$, but not much change in the spleen and lungs in terms of the numbers after H7N9 infection (Figure 5C). In contrast to T cell response, Bu- $1^{+} \mathrm{B}$ cells significantly decreased in the spleen and blood but increased in the lung (Figure 5D), indicating that $B$ cells may be recruited from periphery to lung. These data suggest that $\gamma \delta$ T cells and $C D 8 \alpha^{+} \mathrm{T}$ cells participated in the local immune response in the lung, whereas CD4 T cell and B cell may be responsible for a systemic immune response following H7N9 infection.

\subsection{CD25 Expression on T-Cell Subsets after H7N9 Infection}

CD25 molecule is not only a marker for the identification of chicken Tregs but also for T cell activation [36]. In order to investigate the potential H7N9-induced activation of T-cell subsets, we analyzed the $\mathrm{CD} 25$ expression on $\gamma \delta \mathrm{T}$ cells, $\mathrm{CD} 8 \alpha^{+} \mathrm{T}$ cells, and $\mathrm{CD} 4^{+} \mathrm{T}$ cells. As shown in Figure 6 , $\gamma \delta \mathrm{T}$ and $\mathrm{CD} 8 \alpha^{+} \mathrm{T}$ cells from H7N9-infected chicken were activated with upregulated expression of CD25 in the lung but not in the spleen and blood, compared to that of naïve birds (Figure 6A,B). The increase of MFI of CD25 on these two subsets indicated the upregulated expression of CD25 at the single-cell level (Figure $6 \mathrm{D}, \mathrm{E}$ ). In contrast, there was no difference in the percentages of $\mathrm{CD} 4{ }^{+} \mathrm{CD} 25^{+}$ $\mathrm{T}$ cells between the two groups (Figure $6 \mathrm{C}$ ). However, the MFI of $\mathrm{CD} 25$ on CD4 ${ }^{+} \mathrm{CD} 25^{+} \mathrm{T}$ cells was significantly augmented $(p<0.05)$ in lung and blood in H7N9-infected birds (Figure 6F). These results suggested that H7N9 infection induced the activation of $\gamma \delta \mathrm{T}$ and CD8 $\alpha^{+} \mathrm{T}$ cells. 
A
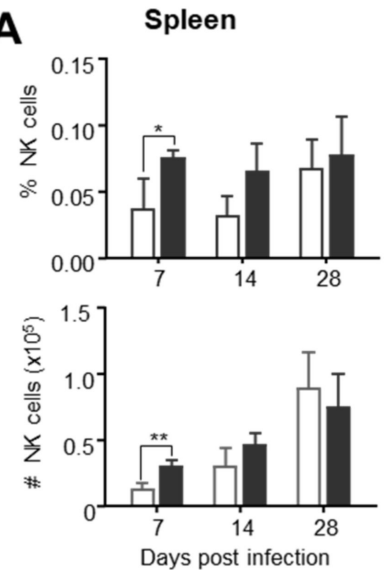

B
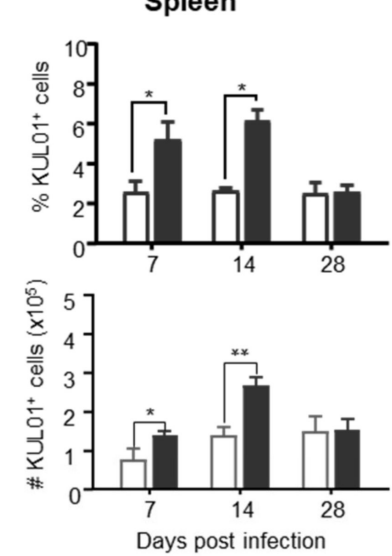

Lung
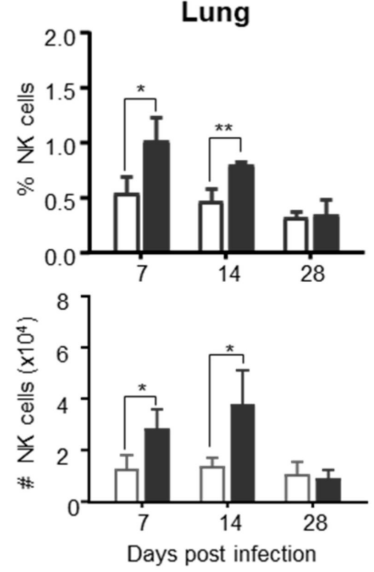

Lung
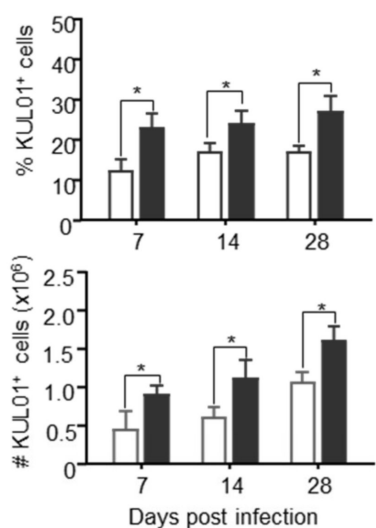

Blood
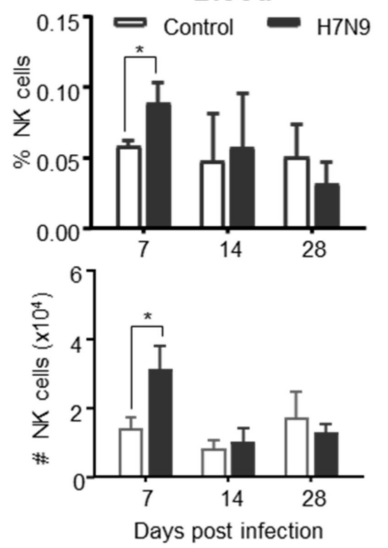

Blood
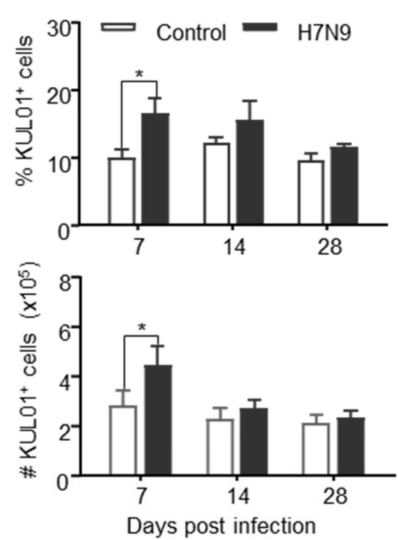

C

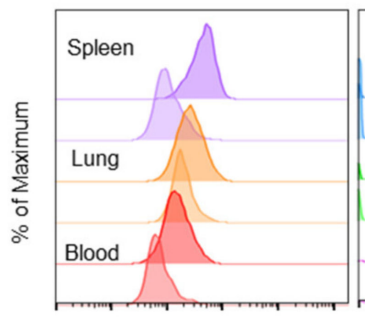

MHC-II-PE/Cy7

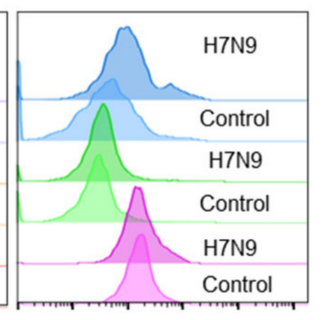

CD11C-APC
D

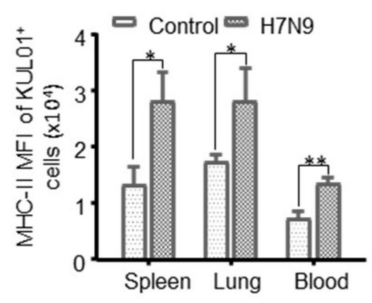

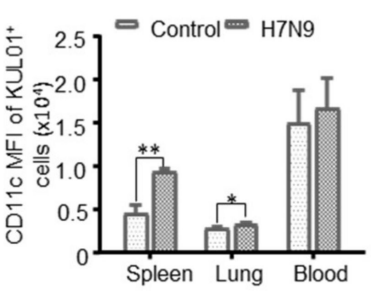

Figure 4. The dynamic changes of the chicken innate immune cells after H7N9 infection. Single cells were isolated from the spleen, lung, and blood of non-infected (Control) and H7N9-infected (H7N9) chickens at 7, 14, and $28 \mathrm{dpi}$ and stained with antibodies from Panel 1 or Panel 2. Each subset of immune cells was analyzed by flow cytometry. The percentages and total numbers of $\mathrm{CD}^{-} \mathrm{CD} 8 \alpha^{+} \mathrm{NK}$ cells (A) and $\mathrm{KULO1}^{+}$cells (B) in the spleen, lung, and blood of the two groups were compared, and the total number of indicated cells per organ or $5 \mathrm{~mL}$ blood was calculated. (C) Representative histogram of MHC-II and CD11c expression on KUL01 ${ }^{+}$cells isolated from spleens, lung, and blood of non-infected (Control) and H7N9-infected (H7N9) chickens at 14 dpi. (D) The bar graph shows the geometric mean of fluorescence intensity (MFI) of MHC-II and CD11c expression within $\mathrm{KUL}^{+}{ }^{+}$cells from non-infected and H7N9 infected chickens. The values are representative of six different birds for each group. The mean $\pm \mathrm{SD}$ value are shown $\left({ }^{*} p<0.05,{ }^{* *} p<0.01\right)$. 
A

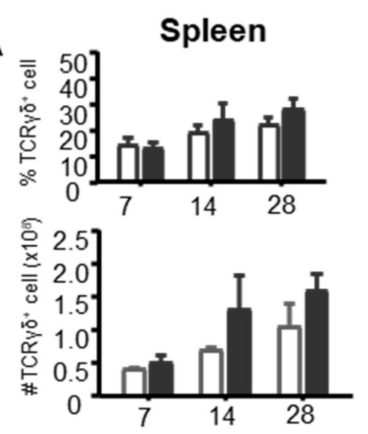

B

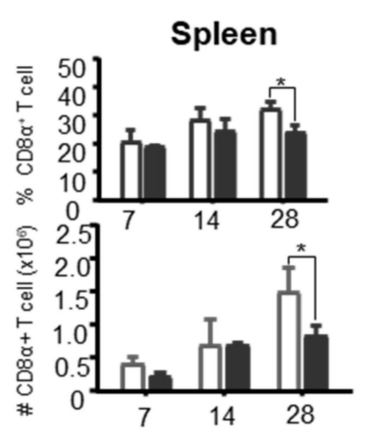

C

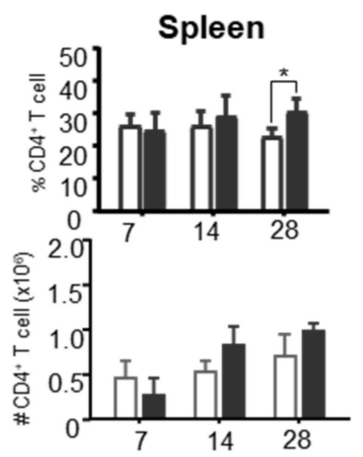

D

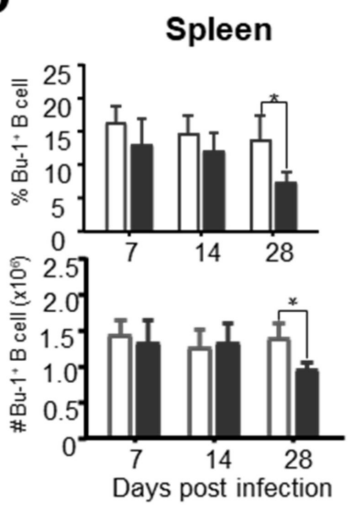

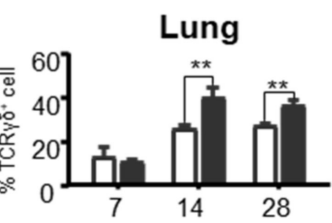

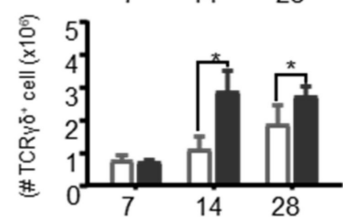

Lung

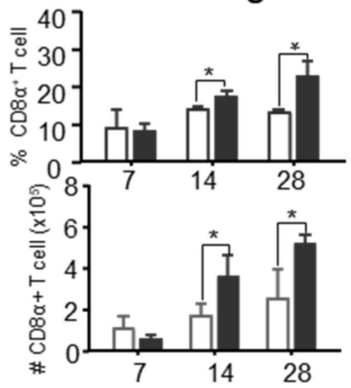

Lung

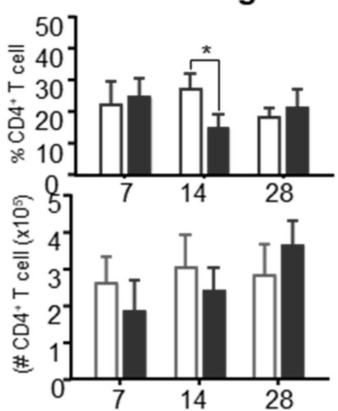

Lung

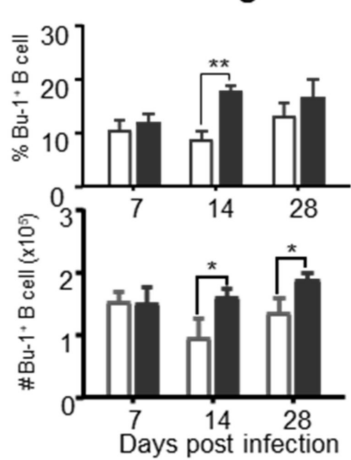

Blood
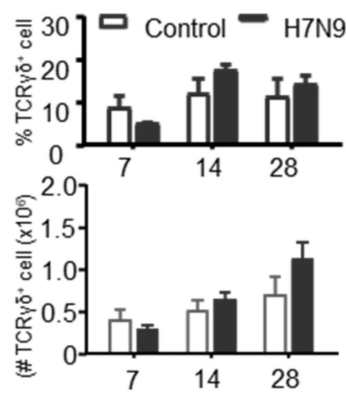

Blood

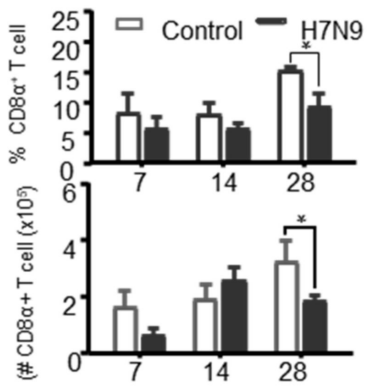

Blood

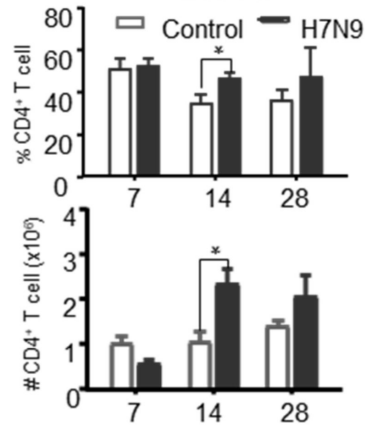

Blood

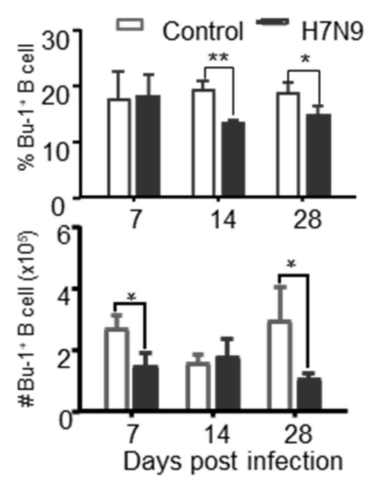

Figure 5. The dynamic changes of chicken's adaptive immune cells after H7N9 infection. Single cells were isolated from the spleen, lung, and blood of non-infected (Control) and H7N9-infected (H7N9) chickens at 7,14, and $28 \mathrm{dpi}$ and stained with antibodies from panel 1 or panel 2. Each subset of immune cells was analyzed by flow cytometry. The percentages and total numbers of $\gamma \delta \mathrm{T}$ cells (A), CD8 $\alpha^{+} \mathrm{T}$ cells $(\mathbf{B}), \mathrm{CD} 4^{+} \mathrm{T}$ cells $(\mathbf{C})$, and Bu- $1^{+} \mathrm{B}$ cells (D) in spleen, lung, and blood were compared between the two groups. The total number of indicated cells per organ or $5 \mathrm{~mL}$ blood was calculated. The values were representative of six different birds for each group. The mean \pm SD value are shown (* $\left.p<0.05,{ }^{* *} p<0.01\right)$. 
A

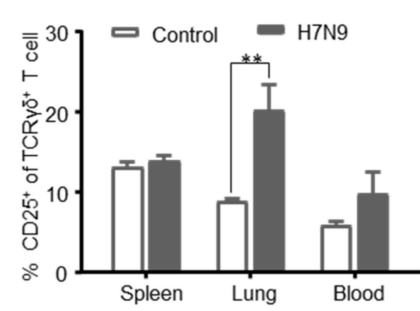

D

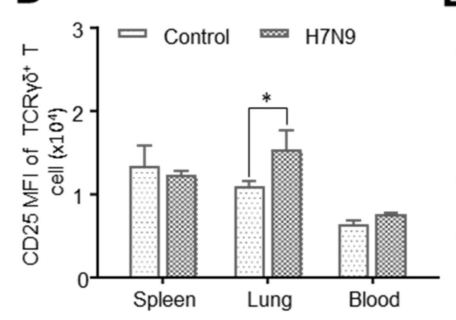

B

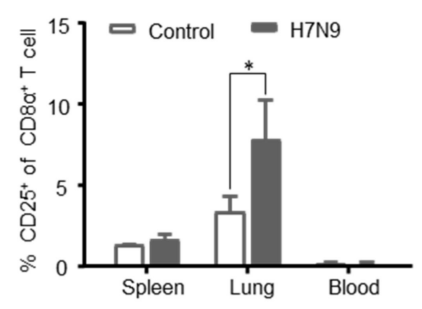

E

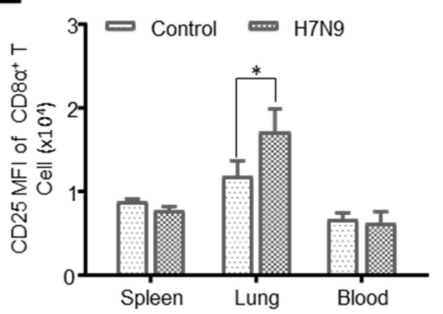

C

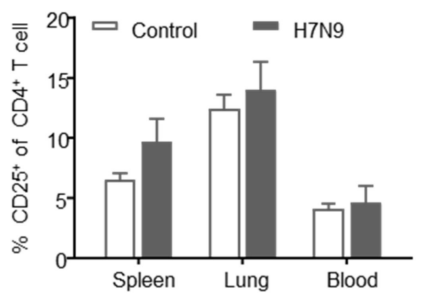

$\mathbf{F}$

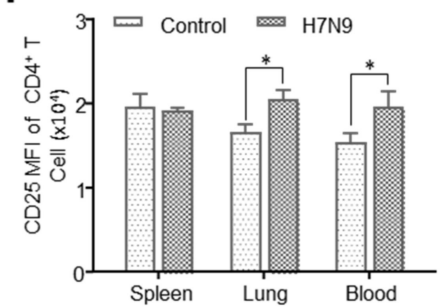

Figure 6. CD25 expression of chicken T cell subtypes after H7N9 infection. Single cells were isolated from the spleen, lung, and blood of non-infected (Control) and H7N9-infected (H7N9) chickens at 14 dpi and stained with antibodies from panel 2. CD25 expression on T-cell subsets was analyzed by flow cytometry. The percentages of TCR $\gamma \delta^{+} \mathrm{CD} 25^{+} \mathrm{T}$ cells $(\mathbf{A}), \mathrm{CD} 8{ }^{+} \mathrm{CD} 25^{+} \mathrm{T}$ cells $(\mathbf{B})$, and $\mathrm{CD} 4{ }^{+} \mathrm{CD} 25^{+} \mathrm{T}$ cells $(\mathbf{C})$ in the spleen, lung, and blood were compared between the two groups. The mean fluorescence intensity (MFI) of CD25 expression on single $\gamma \delta \mathrm{T}$ cells $(\mathbf{D}), \mathrm{CD} 8^{+} \mathrm{T}$ cells $(\mathbf{E})$, and CD4 ${ }^{+} \mathrm{T}$ cells $(\mathbf{F})$ from non-infected and H7N9 infected chickens were compared. The data are representative of six different infected and non-infected birds. The mean \pm SD value are shown $\left({ }^{*} p<0.05,{ }^{* *} p<0.01\right)$.

\section{Discussion}

Immune protection against AIV is mainly mediated by humoral and cellular immune responses [15]. Although HI and NA play a paramount role as a correlate of protection for conventional influenza vaccines, the efficacy of an influenza vaccine is not always correlated with the level of the humoral immune response $[5,6,37]$. Thus, it is necessary to define cellular correlates of immune protection for specific subtypes of AIV. In the present study, the development of a multi-parameter flow cytometry suitable for chicken/birds allowed us to comprehensively analyze the phenotypical changes of innate and adaptive immune cells in chicken, making an important advance toward identifying novel correlates of protection after immunization with vaccines against influenza and other avian viral diseases. Employing this assay, for the first time, our study revealed that $\gamma \delta \mathrm{T}$ and CD8 T cells are activated and, along with KUL01 ${ }^{+}$cells and NK cells, take part in local and systemic cellular immune responses in chicken after AIV H7N9 infection.

Polychromatic flow cytometry is a powerful tool that can be used to analyze multiple functions and phenotypes of a single cell. In chickens, although conventional immune cells such as $\gamma \delta \mathrm{T}$ cells, CD4, CD8 T cells, and monocytes/macrophages were defined using 2 to 4 color flow cytometry in previous studies [26-28], to establish a multi-parameter flow cytometry more than five colors was still challenging due to the limited availability of antibodies to chicken immune cell markers. The current combination of antibodies ( 6 colors for Panel 1 and 7 colors for Panel 2 ) enabled us to immunophenotype almost all the known, characterized distinct immune cells in chickens simultaneously. We attempted to include chicken CD44 as an antigen-experienced T cell marker as per previous studies in chicken [28] and in mammals [38], but $\mathrm{T}$ cells isolated from both naïve and infected birds expressed CD44 ${ }^{\text {hi }}$ completely. Thus, CD44 cannot be used to differentiate T cell activation in outbred chicken in our experience. We also attempted to detect IFN- $\gamma$ expression by T cells through intracellular cytokine staining (ICS), as previously reported $[26,39,40]$, but we could not reproduce reliable intracellular staining of IFN- $\gamma$ even though more than seven clones of anti-chicken IFN- $\gamma$ antibodies that are 
commercially available were tested (data not shown). Further work is needed to establish a better reproducible ICS assay, as well as a cytotoxicity assay of T lymphocytes (CTL) [41] to delineate T cell function in chickens after H7N9 infections.

Chickens have a unique immune system distinct from mammals, characterized by a lack of lymph nodes, an extraordinarily high proportion of $\gamma \delta$ T cells, and a unique organ for B cell development [42,43]. Without a lymphatic draining system, DCs may activate T cells locally without the need to migrate to lymph nodes for $\mathrm{T}$ cell priming that is required in mammals. Indeed, at steady state, we observed that a lot of potential DCs $\left(\mathrm{KUL01}^{+}, \mathrm{MHC}^{-\mathrm{II}^{+}}\right.$, and $\mathrm{CD} 11 \mathrm{c}^{+}$) reside in the lung (Figure 3A,C), which could be associated with the local response of $\gamma \delta \mathrm{T}$ cell and CD8 $\alpha^{+} \mathrm{T}$ cells in the lung after infection (Figure 5). Although the literature states that the frequency of $\gamma \delta \mathrm{T}$ cells are extremely high in chicken $[12,42,43]$, we only observed an average percentage of 3-10\% in all the tested organs from 4-week old chicken. Surprisingly, the percentage of CD4 was so high in blood and so low in the thymus (Figure 3B,D) that it is unclear if this phenotype is a universal characteristic for chicken or not.

While the roles of each subset of immune cells were well defined in mammals during IAV infection [13-15], it was unclear how the chicken immune cells respond to AIV infection or immunization. The present study revealed that KUL01 ${ }^{+}$cells, a subset of putative DC cells, NK cells, $\gamma \delta \mathrm{T}$ cell, CD $8 \alpha^{+}$ T cells, CD4 T cells, and B cells all differentially participated in the host defense against H7N9 infection. $\mathrm{KULO}^{+}$cells were thought to be mainly monocytes and/or macrophages [44]. However, a recent study clearly showed that in vitro differentiated DCs from chicken bone marrow expressed KUL01 [45], suggesting that KUL01 is not exclusively expressed on macrophages, but also on DCs. Interestingly, in this study, in combination with a putative CD11c staining, we identified a subset of $\mathrm{KULO1}^{+}$cells with upregulated CD11c and MHC-II expression (KUL01 ${ }^{+},{\mathrm{MHC}-\mathrm{II}^{+} \text {, and CD11c }}^{+}$) after infection, indicating that this population might be potentially a subset of dendritic cells (Figure $4 \mathrm{C}$ ). However, further characterization of this subset is needed in the future. In addition, a subset of conventional DCs in chicken has been identified, which was phenotypically $\mathrm{KULO1}^{-} \mathrm{MHCII}^{+} \mathrm{CD} 11 \mathrm{c}^{+}$ and exhibited DC-specific core gene expression signatures such as XCR1, ZBTB46, Flt3, and so on [46]. Of note, the anti-CD11c monoclonal antibody (clone 8F2) used in that study is not commercially available and different from the one we used in the present study. The identity of the DC subset identified in this study would be warranted by an in-depth analysis of DC-specific core gene expression signatures. Yu et al. found that splenic $\mathrm{KULO}^{+} \mathrm{MHC}-\mathrm{II}^{+}$cells may act as $\mathrm{M} 1$ and M2-like macrophages in chickens [47], however, in the present study, this population was identified only in 1 out of 3 chickens and not observed in the lung. Chicken NK cells were mainly defined as CD3 ${ }^{-} \mathrm{CD}^{+} \alpha^{+}[24,48,49]$. A previous study showed that and LPAIV H9N2, but no HPAIV H5N1 was able to induce the increase and activation of $\mathrm{CD}^{-} \mathrm{CD} 8 \alpha^{+} \mathrm{NK}$ cells in the lung [24]. As HPAIV H7N9s also emerged, it would be interesting to compare if LPAIV and HPAIV H7N9 virus activate NK cells differentially in the future. It was shown that chicken CD8 T cells mediated immune protection against H5N1 subtype [23]. In this study, chicken CD8 T cells increased and were activated after H7N9 infection; it is thus plausible to speculate that this population participates in protective immunity against H7N9 infection. Similarly, chicken $\gamma \delta$ T cells may also play a protective role, though its role remains to be addressed after H7N9 as evidence showed that $\gamma \delta \mathrm{T}$ cells are able to provide heterotypic immune protection against HPAIV H5N1 infection in mice [21]. It is noteworthy that AIV H7N9 infection induced a systemic response for $\mathrm{KULO}^{+}$cells and NK cells as these cells increased in spleen, lung, and blood whereas $\gamma \delta \mathrm{T}$ cells and CD8 $\alpha^{+}$T cells responded and are activated only in the lung, suggesting AIV H7N9 infection induced a local T cell mucosal immunity. Our results also highlighted the importance to comprehensively dissect the immune response in local tissues of chicken besides PBMCs after infection [28,50].

Overall, the present study established a polychromatic flow cytometry for in-depth analysis of the changes of distinct immune cells in chickens before and after H7N9 infection. Our results for the first time disclosed that H7N9 LPAIV induces distinct local and systemic cellular immune responses in chicken following inoculation via the natural intranasal route and increased our understanding of cellular immunity of chicken to H7N9 AIV infection. The flow cytometric assay developed in this 
study is valuable for analyzing cellular immune responses to AIVs and other avian infectious diseases in order to establish protection criteria.

Author Contributions: Conceptualization, S.S. and X.H.; methodology, X.H. and J.W.; validation, S.S. and X.H.; formal analysis, X.H. and S.S.; investigation, X.H., S.L., L.C. and M.D.; resources, X.L., J.H., M.G., X.W., S.H. and D.P.; data curation, X.H.; writing, X.H. and S.S.; writing-review and editing, S.S.; visualization, X.H.; supervision, S.S.; project administration, X.H.; funding acquisition, X.H. All authors have read and agreed to the published version of the manuscript.

Funding: This work was funded by the National Natural Science Foundation of China (32002293), the China Postdoctoral Science Foundation (2018M642345), the special financial grant from the China Postdoctoral Science Foundation (2019T120473), and a project funded by the Priority Academic Program Development of Jiangsu Higher Education Institutions (PAPD).

Acknowledgments: We thank Jiaqi Li, Fan Zhang, Yunfei Tian, and Shuangjiang He for their help in animal trials, single-cell preparation, and testing.

Conflicts of Interest: The authors declare that they have no conflict of interest.

\section{References}

1. Wang, X.; Jiang, H.; Wu, P.; Uyeki, M.T.; Feng, L.; Lai, S.; Wang, L.; Huo, X.; Xu, K.; Chen, E.; et al. Epidemiology of avian influenza a H7N9 virus in human beings across five epidemics in mainland China, 2013-2017: An epidemiological study of laboratory-confirmed case series. Lancet Infect. Dis. 2017, 17, 822-832. [CrossRef]

2. Shi, J.; Deng, G.; Ma, S.; Zeng, X.; Yin, X.; Li, M.; Zhang, B.; Cui, P.; Chen, Y.; Yang, H.; et al. Rapid evolution of H7N9 highly pathogenic viruses that emerged in China in 2017. Cell Host Microbe 2018, 24, 558-568. [CrossRef]

3. Jiang, W.; Hou, G.; Li, J.; Peng, C.; Wang, S.; Liu, S.; Zhuang, Q.; Yuan, L.; Yu, X.; Li, Y.; et al. Antigenic variant of highly pathogenic avian influenza A(H7N9) virus, China, 2019. Emerg. Infect. Dis. 2020, 26, 379-380. [CrossRef]

4. Kamal, R.P.; Blanchfield, K.; Belser, J.A.; Music, N.; Tzeng, W.P.; Holiday, C.; Burroughs, A.; Sun, X.; Maines, T.R.; Levine, M.Z.; et al. Inactivated H7 influenza virus vaccines protect mice despite inducing only low levels of neutralizing antibodies. J. Virol. 2017, 91. [CrossRef] [PubMed]

5. Stadlbauer, D.; Rajabhathor, A.; Amanat, F.; Kaplan, D.; Masud, A.; Treanor, J.J.; Izikson, R.; Cox, M.M.; Nachbagauer, R.; Krammer, F. Vaccination with a recombinant H7 hemagglutinin-based influenza virus vaccine induces broadly reactive antibodies in humans. mSphere 2017, 2. [CrossRef] [PubMed]

6. Blanchfield, K.; Kamal, R.P.; Tzeng, W.P.; Music, N.; Wilson, J.R.; Stevens, J.; Lipatov, A.S.; Katz, J.M.; York, I.A. Recombinant influenza H7 hemagglutinins induce lower neutralizing antibody titers in mice than do seasonal hemagglutinins. Influenza Other Respir. Viruses 2014, 8, 628-635. [CrossRef] [PubMed]

7. Hu, Z.; Jiao, X.; Liu, X. Antibody immunity induced by H7N9 avian influenza vaccines: Evaluation criteria, affecting factors, and implications for rational vaccine design. Front. Microbiol. 2017, 8, 1898. [CrossRef] [PubMed]

8. Gianchecchi, E.; Torelli, A.; Montomoli, E. The use of cell-mediated immunity for the evaluation of influenza vaccines: An upcoming necessity. Hum. Vaccines Immunother. 2019, 15, 1021-1030. [CrossRef] [PubMed]

9. Shi, L.; Hu, Z.; Hu, J.; Liu, D.; He, L.; Liu, J.; Gu, H.; Gan, J.; Wang, X.; Liu, X. Single immunization with newcastle disease virus-vectored $\mathrm{H} 7 \mathrm{n} 9$ vaccine confers a complete protection against challenge with highly pathogenic avian influenza H7N9 virus. Avian Dis. 2019, 63, 61-67. [CrossRef]

10. Hu, Z.; Liu, X.; Jiao, X.; Liu, X. Newcastle disease virus (Ndv) recombinant expressing the hemagglutinin of H7N9 avian influenza virus protects chickens against $\mathrm{Ndv}$ and highly pathogenic avian influenza a (H7n9) virus challenges. Vaccine 2017, 35, 6585-6590. [CrossRef]

11. Yamayoshi, S.; Uraki, R.; Ito, M.; Kiso, M.; Nakatsu, S.; Yasuhara, A.; Oishi, K.; Sasaki, T.; Ikuta, K.; Kawaoka, Y. A broadly reactive human anti-hemagglutinin stem monoclonal antibody that inhibits influenza A virus particle release. EBioMedicine 2017, 17, 182-191. [CrossRef]

12. Yang, Y.; Dong, M.; Hao, X.; Qin, A.; Shang, S. Revisiting cellular immune response to oncogenic marek's disease virus: The rising of avian T-cell immunity. Cell. Mol. Life Sci. 2020, 77, 3103-3116. [CrossRef]

13. Pizzolla, A.; Wakim, L.M. Memory T cell dynamics in the lung during influenza virus infection. J. Immunol. 2019, 202, 374-381. [CrossRef] 
14. Nussing, S.; Sant, S.; Koutsakos, M.; Subbarao, K.; Nguyen, T.H.O.; Kedzierska, K. Innate and adaptive T cells in influenza disease. Front. Med. 2018, 12, 34-47. [CrossRef]

15. Koutsakos, M.; Kedzierska, K.; Subbarao, K. Immune responses to avian influenza viruses. J. Immunol. 2019, 202, 382-391. [CrossRef]

16. Oslund, K.L.; Baumgarth, N. Influenza-induced innate immunity: Regulators of viral replication, respiratory tract pathology \& adaptive immunity. Future Virol. 2011, 6, 951-962.

17. Kim, T.S.; Hufford, M.M.; Sun, J.; Fu, Y.X.; Braciale, T.J. Antigen persistence and the control of local t cell memory by migrant respiratory dendritic cells after acute virus infection. J. Exp. Med. 2010, 207, 1161-1172. [CrossRef]

18. Kim, T.S.; Braciale, T.J. Respiratory dendritic cell subsets differ in their capacity to support the induction of virus-specific cytotoxic Cd8+ T cell responses. PLoS ONE 2009, 4, e4204. [CrossRef]

19. Stein-Streilein, J.; Guffee, J. In vivo treatment of mice and hamsters with antibodies to asialo Gm1 increases morbidity and mortality to pulmonary influenza infection. J. Immunol. 1986, 136, 1435-1441.

20. Gazit, R.; Gruda, R.; Elboim, M.; Arnon, T.I.; Katz, G.; Achdout, H.; Hanna, J.; Qimron, U.; Landau, G.; Greenbaum, E.; et al. Lethal influenza infection in the absence of the natural killer cell receptor gene Ncr1. Nat. Immunol. 2006, 7, 517-523. [CrossRef]

21. Dong, P.; Ju, X.; Yan, Y.; Zhang, S.; Cai, M.; Wang, H.; Chen, H.; Hu, Y.; Cui, L.; Zhang, J.; et al. Gammadelta T cells provide protective function in highly pathogenic avian $\mathrm{H} 5 \mathrm{n} 1$ influenza a virus infection. Front. Immunol. 2018, 9, 2812. [CrossRef] [PubMed]

22. Qin, G.; Mao, H.; Zheng, J.; Sia, S.F.; Liu, Y.; Chan, P.L.; Lam, K.T.; Peiris, J.S.; Lau, Y.L.; Tu, W. Phosphoantigen-expanded human gammadelta $\mathrm{T}$ cells display potent cytotoxicity against monocyte-derived macrophages infected with human and avian influenza viruses. J. Infect. Dis. 2009, 200, 858-865. [CrossRef] [PubMed]

23. Seo, S.H.; Peiris, M.; Webster, R.G. Protective cross-reactive cellular immunity to lethal a/Goose/ Guangdong/1/96-like H5n1 influenza virus is correlated with the proportion of pulmonary Cd8(+) T cells expressing gamma interferon. J. Virol. 2002, 76, 4886-4890. [CrossRef]

24. Jansen, C.A.; de Geus, E.D.; van Haarlem, D.A.; van de Haar, P.M.; Löndt, B.Z.; Graham, S.P.; Göbel, T.W.; van Eden, W.; Brookes, S.M.; Vervelde, L. Differential lung Nk cell responses in avian influenza virus infected chickens correlate with pathogenicity. Sci. Rep. 2013, 3, 2478. [CrossRef] [PubMed]

25. Soloski, M.J.; Chrest, F.J. Multiparameter flow cytometry for discovery of disease mechanisms in rheumatic diseases. Arthritis Rheum. 2013, 65, 1148-1156. [CrossRef]

26. De Boever, S.; Croubels, S.; Demeyere, K.; Lambrecht, B.; De Backer, P.; Meyer, E. Flow cytometric differentiation of avian leukocytes and analysis of their intracellular cytokine expression. Avian Pathol. 2010, 39, 41-46. [CrossRef] [PubMed]

27. Taebipour, M.J.; Dadras, H.; Nazifi, S.; Afsar, M.; Ansari-Lari, M. Evaluation of blood monocyte and lymphocyte population in broiler chicken after vaccination and experimental challenge with newcastle disease virus. Vet. Immunol. Immunopathol. 2017, 190, 31-38. [CrossRef]

28. Dalgaard, T.S.; Norup, L.R.; Pedersen, A.R.; Handberg, K.J.; Jørgensen, P.H.; Juul-Madsen, H.R. Flow cytometric assessment of chicken $\mathrm{T}$ cell-mediated immune responses after newcastle disease virus vaccination and challenge. Vaccine 2010, 28, 4506-4514. [CrossRef]

29. Seliger, C.; Schaerer, B.; Kohn, M.; Pendl, H.; Weigend, S.; Kaspers, B.; Hartle, S. A rapid high-precision flow cytometry based technique for total white blood cell counting in chickens. Vet. Immunol. Immunopathol. 2012, 145, 86-99. [CrossRef]

30. He, L.; Liu, D.; Hu, J.; Sun, W.; Gao, R.; Shi, L.; He, D.; Li, B.; Wang, X.; Gu, M.; et al. A comprehensive comparison of the fifth-wave highly pathogenic and low-pathogenic H7n9 avian influenza viruses reveals potential threat posed by both types of viruses in mammals. Transbound. Emerg. Dis. 2018, 65, 1459-1473. [CrossRef]

31. Shang, S.; Siddiqui, S.; Bian, Y.; Zhao, J.; Wang, C.R. Nonclassical Mhc Ib-restricted Cd8+ T cells recognize mycobacterium tuberculosis-derived protein antigens and contribute to protection against infection. PLoS Pathog. 2016, 12, e1005688. [CrossRef] [PubMed]

32. Dalgaard, T.S.; Norup, L.R.; Rubbenstroth, D.; Wattrang, E.; Juul-Madsen, H.R. Flow cytometric assessment of antigen-specific proliferation in peripheral chicken $\mathrm{T}$ cells by Cfse dilution. Vet. Immunol. Immunopathol. 2010, 138, 85-94. [CrossRef] [PubMed] 
33. Wu, Z.; Rothwell, L.; Young, J.R.; Kaufman, J.; Butter, C.; Kaiser, P. Generation and characterization of chicken bone marrow-derived dendritic cells. Immunology 2010, 129, 133-145. [CrossRef]

34. Göbel, T.W.; Kaspers, B.; Stangassinger, M. Nk and T cells constitute two major, functionally distinct intestinal epithelial lymphocyte subsets in the chicken. Int. Immunol. 2001, 13, 757-762. [CrossRef]

35. Qu, C.; Brinck-Jensen, N.S.; Zang, M.; Chen, K. Monocyte-derived dendritic cells: Targets as potent antigen-presenting cells for the design of vaccines against infectious diseases. Int. J. Infect. Dis. 2014, 19, 1-5. [CrossRef]

36. Shanmugasundaram, R.; Selvaraj, R.K. Regulatory T cell properties of chicken Cd4+Cd25+ cells. J. Immunol. 2011, 186, 1997-2002. [CrossRef]

37. Gijzen, K.; Liu, W.M.; Visontai, I.; Oftung, F.; van der Werf, S.; Korsvold, G.E.; Pronk, I.; Aaberge, I.S.; Tütto, A.; Jankovics, I.; et al. Standardization and validation of assays determining cellular immune responses against influenza. Vaccine 2010, 28, 3416-3422. [CrossRef]

38. Misumi, I.; Cook, K.D.; Mitchell, J.E.; Lund, M.M.; Vick, S.C.; Lee, R.H.; Uchimura, T.; Bergmeier, W.; Mieczkowski, P.; Pardo-Manuel de Villena, F.; et al. Identification of a locus in mice that regulates the collateral damage and lethality of virus infection. Cell Rep. 2019, 27, 1387-1396. [CrossRef]

39. Andersen, S.H.; Vervelde, L.; Sutton, K.; Norup, L.R.; Wattrang, E.; Juul-Madsen, H.R.; Dalgaard, T.S. Quantification and phenotypic characterisation of peripheral Ifn- $\Gamma$ producing leucocytes in chickens vaccinated against newcastle disease. Vet. Immunol. Immunopathol. 2017, 193-194, 18-28. [CrossRef]

40. Ariaans, M.P.; van de Haar, P.M.; Lowenthal, J.W.; van Eden, W.; Hensen, E.J.; Vervelde, L. Elispot and intracellular cytokine staining: Novel assays for quantifying $\mathrm{T}$ Cell responses in the chicken. Dev. Comp. Immunol. 2008, 32, 1398-1404. [CrossRef]

41. Wattrang, E.; Dalgaard, T.S.; Norup, L.R.; Kjaerup, R.B.; Lunden, A.; Juul-Madsen, H.R. Cd107a as a marker of activation in chicken cytotoxic T cells. J. Immunol. Methods 2015, 419, 35-47. [CrossRef] [PubMed]

42. Kaspers, B.; Thomas, W.F.G. The avian immune system. In Encyclopedia of Immunobiology; Michael, J.H.R., Ed.; Academic Press: Oxford, UK, 2016; pp. 498-503.

43. Adrian, L.S.; Thomas, W.G. Chapter 5-Avian T cells: Antigen recognition and lineages. In Avian Immunology, 2nd ed.; Karel, A., Schat, B.K., Kaiser, P., Eds.; Academic Press: Boston, MA, USA, 2014; pp. 91-102.

44. Mast, J.; Goddeeris, B.M.; Peeters, K.; Vandesande, F.; Berghman, L.R. Characterisation of chicken monocytes, macrophages and interdigitating cells by the monoclonal antibody Kul01. Vet. Immunol. Immunopathol. 1998, 61, 343-357. [CrossRef]

45. Van den Biggelaar, R.H.G.A.; Arkesteijn, G.J.A.; Rutten, V.P.M.G.; van Eden, W.; Jansen, C.A. In vitro chicken bone marrow-derived dendritic cells comprise subsets at different states of maturation. Front. Immunol. 2020, 11, 141. [CrossRef]

46. Vu Manh, T.P.; Marty, H.; Sibille, P.; Le Vern, Y.; Kaspers, B.; Dalod, M.; Schwartz-Cornil, I.; Quere, P. Existence of conventional dendritic cells in gallus gallus revealed by comparative gene expression profiling. J. Immunol. 2014, 192, 4510-4517. [CrossRef]

47. Yu, K.; Gu, M.J.; Pyung, Y.J.; Song, K.D.; Park, T.S.; Han, S.H.; Yun, C.H. Characterization of splenic $\operatorname{Mrc1}(\mathrm{Hi}) \mathrm{Mhcii}(\mathrm{Lo})$ and Mrc1(Lo)Mhcii(Hi) cells from the monocyte/macrophage lineage of white leghorn chickens. Vet. Res. 2020, 51, 73. [CrossRef]

48. Jansen, C.A.; van de Haar, P.M.; van Haarlem, D.; van Kooten, P.; de Wit, S.; van Eden, W.; Viertlböck, B.C.; Göbel, T.W.; Vervelde, L. Identification of new populations of chicken natural killer (Nk) cells. Dev. Comp. Immunol. 2010, 34, 759-767. [CrossRef]

49. Göbel, T.W.; Chen, C.L.; Shrimpf, J.; Grossi, C.E.; Bernot, A.; Bucy, R.P.; Auffray, C.; Cooper, M.D. Characterization of avian natural killer cells and their intracellular Cd3 protein complex. Eur. J. Immunol. 1994, 24, 1685-1691. [CrossRef]

50. Qiang, F.; Youxiang, D. The effects of H9n2 influenza a on the immune system of broiler chickens in the Shandong province. Transbound. Emerg. Dis. 2011, 58, 145-151. [CrossRef]

Publisher's Note: MDPI stays neutral with regard to jurisdictional claims in published maps and institutional affiliations. 